\title{
THE CONTRIBUTION OF LITERATURE TEACHING IN LEARNER'S ABILITY TO RESPOND TEXT
}

\author{
Nur Antoni E.T. \\ noor_anthoni@yahoo.com \\ IAIN Syekh Nurjati Cirebon
}

\begin{abstract}
Abtract : Many discussions about the benefit of literary work and literature teaching lead the presence of this research. It appears to reveal the process of literature teaching in responding literature. This research explores about EFL learner's ability in responding literary text whether it is directly or indirectly. This research, therefore, reveals the involvement of emotion, experience, and interest while responding text. This research also reveals the engagement between EFL learners and text based on some criteria which have stated above. Another problem is the way EFL learner respond text appropriately especially literary text. This research used case study because this research attempts to describe engagement between reader and literary work which pointed out by reader response. This research also wants to describe the contribution of literature teaching behind learners' process in responding it. The researcher found contribution of literature teaching from learners' involvement as respondents in this research, that is, learners involved their personal experience in responding text as aesthetic demand. This is the learning objective of "Literary Work Analysis" course and it means that the expected achievement in this course is achieved.
\end{abstract}

Keywords : EFL, lietrature work, literature teaching, students responds.

\section{BACKGROUND}

Literature is learnt by EFL learners to reveal the meaning and to apply the moral value inside literary work well. Literature provides enjoyment to EFL learner so they can engage with text easily if they can engage with it. If they have found the way to engage with literary text so they can engage with another text type. Zhen (2012) states that learning literature can help students learn about the language in all-round fields because literature can supply the most authentic materials in various forms and of different kinds in their language learning". This research written because of some problems background. Creswell (2012) states that research problems are the educational issues, controversies, or concerns that guide the need for conducting a study.

The first problem is the way EFL learner respond text appropriately especially literary text in this case. Each learner has their own favorite text whether literary or nonliterary text. In this case, literary text commonly responded by aesthetic reading but sometimes EFL learners still confuse to differ between aesthetic and efferent reading Baker \& Wigfield (1999). They actually intent to respond literary text aesthetically but 
they just explain the information inside text without involve their emotion, experience, and so on. This research, therefore, reveals EFL learner's ability in responding text well based on what they learnt in literary course. Lobo (2013) states, for her, efferent reading is reading for information, while aesthetic reading is reading to experience the text.

Those aims in this research provide the importance for EFL learners and teaching literature especially in English Language Teaching, IAIN Syekh Nurjati Cirebon. In EFL learner side, this research can guide them the way to respond text appropriately. It also shows them the things must involve in responding text to make it sense. Triastuti (2011) states that they need to fully beware of specific characteristics of text types so as to enable them to provide sufficient models of text and to transform the input tools into appropriate learning material.

This research also has considered importance for teaching literature in English language teaching especially for university level. The lesson about literature actually presents in senior high school but it does not explored flawlessly. English language teaching in university especially in IAIN Syekh Nurjati Cirebon has provided some courses about literary course, "Introduction to Literature" and "Literary Work Analysis" for example. This research can assist the lecturers to observe the motivation, the interest, and the ability level of college students to respond some literary works. The lecturer can also consider the appropriate text, method, and so forth for literature teaching in classroom. Hence, in the RRT the construction of meaning in the personal literacy experience is the main characteristic when thinking of the connection between the reader and the text (Garzon \& Pena, 2015). The theory that adopted in this research is Reader Response Theory by Rosenblatt. Rosenblatt's reader response theory has a long history of being connected to print text, but as the language arts classroom evolves and technology broadens the realm of literacy, theory must adapt as well (Sanders, 2012).

\section{METHOD}

This research is held in IAIN Syekh Nurjati Cirebon which involves EFL learners of English Language Teaching department. Those learners oblige to respond two literary works from different classification, such as; poet, topic, length, the place it arises, and so on. Those literary works are also considered from the complexity level, familiar issue, and so forth. The data analyzed in this research are learner's spoken and written response toward the chosen literary work, the interview result with EFL learner, the interview result with literature lecture, syllabus, observational checklist and video.

The researcher chooses three respondents from fourth selected EFL learners. They are EFL learners who have joined "Introduction to literature" and "Literary Work Analysis" course. The other is two Literature lectureres of those lectures.

Case study is chosen in this study because this attempts to describe engagement between reader and literary work which pointed out by reader response. This research also wants to describe the contribution of literature teaching behind learners' process in responding literary work. The goal is to arrive at a detailed description and understanding of the entity (the "case") (Ary et al., 2010).

The description from the result of reader response leads the researcher to reveal EFL learner's ability in responding text, and the contribution of literature teaching in learner process to respond text. Lodico et al. (2006) states that case study research is a form of 
qualitative research that endeavors to discovermeaning, to investigate processes, and to gain insight into and in-depth understandingof an individual, group, or situation. It also can help researcher to know the things related to the successful of reader to engage with literary work. The literary work must hold out some link with the reader's own past and present preoccupations, emotions, anxieties, ambitions (Rosenblatt, 1994).

\section{Techniques and Instruments of Collecting Data}

The technique and instrument used in this qualitative research is observation, document and interview.

The researcher uses interview for some importance in this research. The interview is implemented four times. The first interview is used to know about respondent's life background, their interest, ability, and motivation toward reading activity especially reading literary work, their experience to respond some texts, and so forth. It also used to select 3 respondents from four EFL learners based on respondents' criteria. The second interview is implemented to get data from lecturer lecturers. The third interview is applied to reveal EFL learner's interest, ability, and others toward two literary works responding directly. The last interview is used to explore more their opinion when they joined literature teaching and their explanation about literature teaching condition they have ever attended. Hwang (2007) states that it has been claimed that one of the roles of literature is to inculcate moral values through the teaching of morality.

The next technique is observation which is implemented when learners' reading process and direct response applied. The researcher observes the way EFL learners read and understand the literary work. The researcher then observes learner's way when they respond the literary work directly. This connects with their mindset and experirince. Hughes (2007) stated, "If we want our students to understand how literature, and poetry in particular, brings them to a deeper understanding in life, we need to find meaningful ways to engage them with literature". Herlina (2016) states that based on this assumption teaching literature then starts from an aesthetic stance, proceeds through reader-response, and ultimately with critical analyses. Texts do not semiotically exist without readers, but neither do readers exist without texts (Lehtonen, 2000). Beach (1993) strenghtent to state that rather than em-phasize formalist analysis of a text, the primary goal of instruction from atransactional perspective is to foster students' trust in the expression oftheir own unique experience with a text.

The last technique which used in this research is document. The document here is the syllabus from lecturer and written response from the respondents.

\section{Data Analysis}

The researcher has stated in previous discussion that this research uses qualitative research. It, then, concerns on case study as one of qualitative research type. The data analysis, therefore, must provided in qualitative approach.

The researcher, then, formulates some steps to analyze tha data.. This is the analysis session after all data is collected:

1. The researcher analyzes the interview result from all respondents to check their ability, interest, motivation and the things related to reveal learner's response. The researcher also uses the first interview to choose three respondents from four selected EFL learners. 
2. The researcher analyzes the interview result from literature lecturers to reveal the literature teaching strategy, literature response process, and so forth.

3. The researcher analyzes syllabus from two literature lecturers to be related with the interview result with literature lecturers and learners' response result.

4. The researcher relates learner's interview result with the learner's response result whether directly or indirectly.

5. The researcher relates the interview result and syllabus from literature lecture with the learner's response result whether directly or indirectly.

6. The reseracher, then, determines the result or conclusion from the data analysis.

\section{FINDINGS}

\section{Literature Teaching: Planning}

The educators whether they are lecturers or teachers, they must still consider the teaching administration. They must prepare the topic, the learning sources, the approach, the strategy, and so forth. It guides lecturers/teachers to manage their class and to achieve the learning objective flawlessly. It directs them to present their teaching well so they never loss direction in their class. Here is the interview result with two literature lecturers about their planning in literature course. The interview discusses about planning of syllabus, lesson plan, topic, and learning sources.

This is the first appearance of the literature course syllabus made by the first lecturer. The first page shows head of cover containing this writing "ENGLISH LANGUAGE TEACHING DEPARTMENT, TARBIYAH AND TEACHER TRAINING FACULTY, SYEKH NURJATI STATE ISLAMIC INSTITUTE CIREBON". The head of cover shows an identity of the institute or university where the literature course taught. This point is important to be involved because it makes the syllabus looked formal.

The next point is the information of the syllabus including the name of course, the name of lecturer, and the time of the syllabus applied. The name of course is Introduction to English Literature, there is also the name of lecturer inside, and the syllabus is applied for fourth semester in 2015-2016. This information aims to show learners about the name of course they learn, the name of lecturer of this course, and the period of this course applied. This point actually is better if there is some additional like lecturers' phone number, email, and so forth.

Then the syllabus shows Description of this course containing this writing,

This course is designed to gain the understanding of students' literature knowledge. The students will study the principle genre of literature with emphasis placed on literary terminology, devices, structure, and interpretation. Upon completion, students will be able analyze and respond both verbally and in written form, to literary works in their historical and cultural context.

This description aims to describe the ability which gained by learners after they follow each activity provided in this course. The lecturer focuses on some things in this description, such as; encouraging learners to improve their literature knowledge and guiding learners to analyze and to respond literary text in oral and written form in learners' cultural and historical context.

The next point is Course Objective. It is containing this writing,

To practice reading critically, asking pertinent questions about what has been read and evaluating underlying assumptions and relevant ideas; To study a range of literary text 
that are rich in quality and representative of different literary forms and historical periods; To deal with the "whats" and "hows" of literary text; To write critical essays with good insight and argument; To be familiar with literary terms and how they are used in text; To recognize that literature is the description of human experience both historically and in the present

This objective is the thing which is reached in this course. The lecturer aims to make learner read various literary works and evaluate their reading. He emphasized learner to relate these words "whats" and "hows" every they read literary work. He also commands learners to write critical essay after learners understand many literary terms.

The course objective is good because it involves cognitive, affective, and psychomotor aspect. The cognitive aspect here is the literary knowledge toward literary terms and ability to analyze text which gained by learners. The affective aspect here is the involvement of learners' emotion when they read and engage with text. The psychomotor aspect here is creating critical essay. It fulfills learners' ability in understanding of literary knowledge, literary terms for instance, and applies it in literary work. The next point is Class Participation containing this writing,

"Students are expected to ask relevant questions, read the material assigned, complete homework, and write papers. The assignments must be turned in on time for full credit".

The class participation emphasizes on learners' activeness, learners' reading activity, and learners assignment schedule. Those points are the things that assessed by lecturer.

The submitted documents or files are going to be the students' responsibility. Technical problem should not be used to excuse for missed assignment: Evaluation tools, Exams, Weekly novel/journal, Essays over novels read, Essays over literature terms in text, Short essays, Poetry essays, Weekly discussion board.

Those are the learners' responsibility in this course. They must collect those assignments including reading, writing, speaking, and listening skill. This point also has some repetition word in same activity like writing essay. It is written four times whereas they actually discussed about three kinds of essay. This point also contains one confuse thing that is Evaluation tools because there is no any further explanation about this.

The next point is Students Attendance. It is containing this writing,

In class attendance is expected by regularly submitting homework and writing assignment. It is your duty to withdraw from the class if it is not working out for you. If you do not withdraw and fail to complete work in a timely manner, a grade less than $B$ will be assigned.

This point discusses the submission of an assignment on time. Learners get score less than " $\mathrm{B}$ " if they don't oblige this rule. This point should explain the number of learners' attendance in classroom, some errors like absent, permission, getting sick and so on.

The next point is learning description for 16 meetings packed in table. This point contains some points, such as; week, final competence planned, lecture material, lecture form, indicator measure, and time allocation. Those points are provided for each meeting. The first meeting is the example. It is regarded as the first week because this course is applied once a week. Its final competence planned is "Able to understand 
lecture contract and Able to explain the definition of Literature and it's genre". The lecture material is lecture contract and literature and its' genre. Its lecture form or the activity in classroom is speech and group discussion. Its indicator measure is "Able to mention the topic, purpose and mark criteria of Introduction to Literature, Able to explain Literature definition, and Able to mention each type of literature/ its' genre". Its time allocation is 100 minutes. This is the first meeting so all points discuss about learning contract for further meetings. There is also information about mid-test in eighth meeting and final test in fourteenth meeting.

The learning design has fulfilled the learning objective. There are various activities in each meeting, such as; speech, group discussion, two groups debate, panel discussion, practice for analyzing, and presentation. The indicator measure in all meetings are appropriate with the learning student outcome. The learning activity design supports learners' understanding in literature because it contains many practices. The activities invite learner to involve inside actively. The last point is signature of Head of English Language Teaching Department and Quality Assurance of TBI. Those signatures mean that this syllabus is accepted. It is allowed to apply in the literature teaching.

Those are discussions about syllabus component from the first lecturer. The next discussion is about syllabus component from the second lecturer. The syllabus from the second lecturer is in Indonesian Language. After that the researcher analyzes the syllabus component with its use from experts.

The second lecturer said that he made syllabus by determining its course description, objective, and then kind of activities should be done by students, and of course evaluation process. He, then, mentioned about innovation before he clarified, "As an innovation, I should modify the previous syllabus into the new one for the next class". Those points always modified in each year so the lecturer always modifies his syllabus to make it appropriate with the need of learners and education demand. He also aims to give such innovation in his teaching. It is certainly based on his reflection from previous teaching. He found the weakness and advantages in his teaching management therefore he gives modification in his syllabus for the next teaching season.

The first point in this syllabus is the presence of head of cover. It is containing this writing "KEMENTERIAN AGAMA RI, INSTITUT AGAMA ISLAM NEGERI (IAIN) SYEKH NURJATI CIREBON, FAKULTAS ILMU TARBIYAH DAN KEGURUAN (Religion Ministry of RI, Syekh Nurjati State Islamic Religion Institute, Faculty of Teaching and Teacher Training) Address: Perjuangan Street By Pass Sunyaragi Telp./Fax (0231) 481264/489926 Cirebon Website: www.web iaincirebon. ac.id/ tarbiyah, E-mail: fitk@iaincirebon.ac.id. The lecturer completes the head of cover by the address of the institute, website, and email. It is also accompanied by the information containing this writing "RANCANGAN PEMBELAJARAN SEMESTER (RPS), FAKULTAS ILMU TARBIYAH DAN KEGURUAN, IAIN SYEKH NURJATI CIREBON, SEMESTER GANJIL TAHUN AKADEMIK 2016/2017" (Lesson Plan in Semester, Faculty of Teaching and Teacher Training, Odd Semester of Academic Year 2016/2017.

The next point is Identity. It contains "Department: English Teaching, Lecture name: Literary Work Analysis, Lecture Code:, Semester/SKS: 2 sks, Type of Lecture: 
Compulsury/ prerequisite: -, there is also the name of lecturer inside". It is added by the name of department, the number of learning credit, and kind of the course.

The third point is Capaian Pembelajaran. It's containing this writing: Sikap/Prilaku: a. Menghargai karya orang lain. b. Mendorong minat membaca. $c$, Menunjukkan rasa percaya diri ketika bekerja sendiri dan kooperatif dalam aktivitas kelompok. Pengetahuan: a. Mengenal beberapa tokoh sastra beserta teorinya. $b$. Mengidentifikasi produk sastra berdasarkan genrenya c. Memahami perbedaan jenis jenis kritik sastra $d$. Menganalisa produk sastra melalui proses membaca, diskusi dan tugas menulis. Kemampuan/Keterampilan: a. Mengembangkan kemampuan membuat class \& chapter review dari beberapa momen pembelajaran di kelas dan dari buku yang dibaca b.Membuat respon bacaan sebagai bentuk apresiasi karya sastra $c$. Mempresentasikan hasil kerja.

In English it can be interpreted that the third point is The Goal/aim of learining. It;s conaining: a, Appreciating other work b. Support reading motivation c, Showing self confidence when work alone and cooperative in group. Knowledge: a. Knowing literature authors and their theories. b Indentifying literature product based on it's genre. c, Understanding the differences of literature critics types through reading process, discussion and writing task, Competence/skills: a. Developing the ability in making class and chapter review from some learning in class b. Making reading respons as literature appreciation form. c. Representing literary work.

This point involves affective, knowledge, and psychomotor aspect that focus on the knowledge about literary work and the ability to respond literary work. This point is combination of learning objective and learning outcome. It is good because it involves cognitive, affective and psychomotor aspect. Learners are invited to join literature course in the higher level than before. The basic knowledge of literature which gained by learners in previous literature course are applied in this course. It helps learner to respond text critically. They have mastered to analyze intrinsic and extrinsic aspect in literary work so this is their session to engage what they understand from text with the broader aspect that it the reality, their life or their experience for instance. The fourth point is Deskripsi Mata Kuliah. It is containing this writing:

Mata kuliah ini mengajak para mahasiswa untuk memahami teori sastra, menganalisa, menginterpretasi dan merespon secara kritis prosa dan puisi sebagai bentuk apresiasi karya sastra. Ide dasar yang ditawarkan pada mata kuliah ini adalah penanaman pada mahasiswa bahwa ada cara spesifik untuk membaca, menikmati dan menganalisa produk sastra. Mata kuliah ini memposisikan setiap mahasiswa sebagai pembaca yang unik. Mata kuliah ini diorkestrasi dengan cara yang benar-benar menantang mahasiswa untuk berfikir secara kritis terhadap produk sastra yang dianalisis. Oleh karena itu, mata kuliah ini diracik pada aliran praktik lalu dialirkan pada tataran teoretis secara bertahap.

This point focuses on learners' ability to understand, to analyze, to interpret, and to respond literary work critically.

The next point is Metode dan Pendekatan Perkuliahan. It is containing the writing,

Perkuliahan Introduction to Literature menggabungkan metode konservatif-ceramah - yang bersifat interaktif dan kritis plus diskusi serta analisis reguler di setiap pertemuan. Bimbingan di luar kelas untuk membantu proses kreatif mahasiswa dalam membaca dan menulis diadakan di luar jam kelas. Karena mata kuliah ini bersifat 
integrated, maka setiap minggu mahasiswa diajak secara cermat dan cerdas untuk merampungkan tugas tertulis (class review dan chapter review).

It means that the next point is Lecture Approach and Method. It is containing in the writing. The lesson of Introduction to Literature is combining conservative method - speechinteractively- and critics plus discussion also regular analysis in every meeting. Guidance outside of class for helping students creative process in reading and writing is commited out of class hour. Because this lecture is integretedetive, hence every week the students are invited intelegently and accuratelyto fulfill written task (class review and chapter review).

This point focus on the method applied in classroom, such as; lecturing, discussion, analysis, guiding for class review and chapter review. The methods are good but it is better if other methods involved inside.

The next point is lecture management and knowledge material. There is table that describe about "weekly, the final competence hoped, literature material, Literature type, Learning time, Evaluation type, and mark quality". Those points are applied for sixteen meetings and two additional meetings for remedial session. One of the example is the implementation of first meeting. The first meeting has expected ability that is introducing some literature people with their theory. The learning sources are course introduction and the material about "what is literature?" and "why is it important?". The learning method is interactive lecturing. This meeting needs 100 minutes to apply all materials. The assessment indicator is class and chapter review. This meeting has score about five.

The lecturer provides some test like, two minutes challenge and final task. Remedial is also provided in the seventeenth and eighteenth meeting. It can help learner to upgrade their score. The lecturer has designed the learning outcome, learning material, and learning activity well. They are suited with the learning study outcome before. The lecturer equalizes theory and practice in his teaching by delivering knowledge about various literary schools and short explanation about figurative language. The lecturer also guides learners in responding text process.

The lecturer provides some test like, two minutes challenge and final task. Remedial is also provided in the seventeenth and eighteenth meeting. It can help learner to upgrade their score.

The lecturer has designed the learning outcome, learning material, and learning activity well. They are suited with the learning study outcome before. The lecturer equalizes theory and practice in his teaching by delivering knowledge about various literary schools and short explanation about figurative language. The lecturer also guides learners in responding text process. The learners' ability in literature theory and practice must be increased because this course leads learners to learn about language aspect in literature again. They also pass some practices by responding various texts.

The next point is Reference. The lecturer provides some references which can help learners to add their reading reference and to improve their knowledge about literature.

The last point is the signature. The signature comes from the lecturer, secretary of department, and quality assurance of TBI. Those signatures formalized this syllabus.

\subsection{Lesson Plan for Literature Teaching}

The first lecturer replied that he didn't create any lesson plan. He added that in college context, syllabus and lesson plan are organized together in RPS (Rencana 
Pembelajaran Semester). So he doesn't need to create any lesson plan because he has already prepared things he applies in class inside the syllabus, it's called as RPS.

The second lecturer explained, I combined independent study and classroom activities to learn this course in each chapter, which is focused on a specific topic. Class time were spent actively reviewing and practicing the materials in a variety of activities such as responding to some literary works etc. It means that he has actually designed everything in his syllabus including the planning for his teaching.

Lesson plan is the smaller part than syllabus. If the syllabus is designed for one semester so the lesson plan is designed for one meeting. The lesson plan itself as the description of one point in syllabus. The lesson plan also describes teaching and learning process in one meeting completely. The learning sources description also put inside.

\subsection{Literature Teaching: Implementation}

The next stage is "Implementation". This is the stage when lecturer applies his planning based on the created syllabus. This stage also invites lecturer to apply the planning well. The lecturer also challenged to face many unexpected situations in classroom. The barriers may come from learners, facility, teaching strategy and so on. These are interview results of literature teaching implementation with two lecturers.

\section{Teaching Stages and Techniques in Literature Teaching}

The first lecturer said, "For the warming up, we can give an example with the real things around of us. Then for the abstract things, we can relate it with the movie or television cinema". The lecturer opens the teaching and learning session by inviting learners to relate the topic with the phenomena in real life or in the movie or video. This activity looks like brainstorming. The lecturer attempts to invite learners' knowledge and awareness related to the topic. The lecturer, then, shared learners text to be analyzed.

The second lecturer explained all things and activities related to his teaching stages. He said,

"In certain meeting they could analyze and respond to their favorite

story/song lyric/literary work/short story. It can be started by their favorite

literary work".

The lecturer guide learners to engage with text by providing them special meeting, the session where learners can choose their favorite literary work (story/song/lyric/literary work/short story). The lecturer assumes that learners can engage with text easily because the read and respond their favorite text. They have interest in it and they also save their experience or past memory inside the text.

The second lecturer also said,

"Ok. Moral value?. They found the moral value in the text by

themselves. I could know it by reading their responses. So, I could clarify

when they give the wrong of the moral value they found in the text".

The lecturer gives learners chance to dig up moral value inside text. Then the lecturer aids learners to consider that the moral value they found is correct or not. The lecturer checks learners' moral value inside their response result. Then the lecturer can guide learners to understand the moral value inside text and apply it in real life. 
The first lecturer said,

"In introduction to literature, I facilitated learners with lecturing, analysis, discussions and so on. So I was not only gave them theory but also I provided them analysis session, analysis of figurative language for example".

The lecturer lectures theory of literature because Introduction to Literature course emphasizes to theory. This course is the basic course so learners must learn about the basic of literature course seriously. The practice and the assignment that involved in this course is literary work analysis. The analysis focuses on the form of the literary work, such as; stanza, rhythm, figurative language, and so forth. Then the lecture involves discussion session to facilitate learner before they present the selected topic.

The second lecturer said that he provided various techniques in his teaching. The lecturer does not explore more about his various techniques inside his teaching and learning process. He proposes his various techniques to the example of his learning stages whereas the technique in the learning stages is discussion. However he had put it in RPS. Then he completes his explanation by adding response activity inside.

The first lecturer said that he provided two or three meetings as the session of explanation, lecturing, and every activity that related to discuss about the topic. Those meetings are regarded as enough time to give learners explanation before assignment.

The second lecturer said, "I think 2 meetings would be enough with the responding process". The lecturer provides two meeting for delivering material before he gives learners assignment. He continued that, "In the second meeting they should submit their responses essay they made based on the explanation in previous meeting". It means that the lecturer only provides learner one meeting to explain topic then the next meeting is the assignment collection session.

Time allocation is one of the prominent things that must be considered well. It adjusts the learning activity and task session equally. Learners, therefore, has sufficient knowledge before they face text, they get knowledge about figurative language first before the lecturer commands learner to analyze it inside text. The implementation of time allocation in $R P S$ and in reality is suitable.

\subsection{Learners' Task in Literature Course}

The first lecturer said that he gave learners some assignments such as; analysis, presentation, and so on. Learners are asked to analyze some chosen literary work. They also are commanded to present chosen topic in front of class.

The second lecturer said that he commanded learners to respond around of four or five texts. It actually has considered from the whole meeting in this course. Then the lecturer only provides those numbers of text because he does not give any additional text to be responded by learners.

The second lecturer also gave additional task. He said that he commanded learners to read some required and supported books. It is used as the discussion in learners' weekly journal. So the lecturer involves two kinds of assignment; text response and weekly journal. The lecturer had put chapter review in RPS but the class review (weekly journal) only implemented in each meeting. 


\subsection{Literature Teaching: Evaluation}

\subsubsection{An Assessment and an Evaluation Session in Literature Teaching}

The first lecturer said,

"I provided them an evaluation. If the evaluation could be process together so I commanded them to evaluate it by doing peer evaluating".

The lecturer provides evaluation session by doing peer evaluation. It is applied with partner and accompanied with lecturers' guidance. This activity can show learner about different argument or opinion from other learners.

The second lecturer said, "I checked their work based on the rubric made". The lecturer uses scoring rubric to assess learners' assignment. The rubric contains some indicator that decides learners' score. Some indicator inside are topic, writing organization, idea, word choice, grammar, and so forth. However he could not explain the rubric furthermore. He said,

"I'm so sorry. I should look up the rubric. Sorry". Fortunately, he gave the researcher soft file of Reader Response Rubric.

The reader response rubric contains four scoring levels. The lowest level is level 1 and the highest level is level 4. Each level has different point and criteria.

The level 1 is the lowest level. It offers 10 to 14 points. It has some criteria, such as; Writing has no clear topic, Writing has little or no organization, Little use of details from the text, Limited word choice, Sentences are difficult to read and understand, Writing has major grammar, spelling, and mechanics errors".

The level 2 is the higher level than level 1. It offers 15 to 18 points. It has some criteria, such as;

Topic may include unrelated ideas, Writing has an organization with lapses, Supporting details from text are not fully developed, Your own ideas and thinking were not included, Few creative word choices, Writing has choppy sentences and uses mostly simple sentences, Writing contains many grammar, spelling, and mechanics errors.

The level 3 is the higher level than level 2. It offers 19 to 22 points. It has some criteria, such as;

Focused topic is generally maintained, Writing is organized with some lapses, Some supporting details from text, Writing contains some of your own ideas and thinking, Some creative word choice, Writing has smooth sentences of different lengths, Writing contains some grammar, spelling, and mechanics errors.

Level 4 is the highest level. It offers 23 to 25 points. It has some criteria, such as;

Focused topic throughout writing, Writing is organized, Many supporting details from text, Writing contains your own ideas and thinking, Creative word choice, Writing has smooth sentences of different lengths, Writing contains few grammar, spelling, and mechanics errors.

The first lecturer explained the assessment and the evaluation together. He thought that if it is possible to assess task together so it can be done by doing peer evaluating. William (2013) states that "This is important because it suggests that with 
well-structured peer-assessment, one can achieve better outcomes than would be possible with one adult for every student".

The second lecturer mostly gives response task to learners. He, therefore, always uses scoring rubric to guide him in assessing task. Middle States Comission on Higher Education (2007) states that a rubrics help an evaluator to make explicit, objective, and consistent the criteria for performance that otherwise would be implicit, subjective, and inconsistent if a single letter grade were used as an indicator of performance.

Both of lecturer provided evaluation session. The first lecturer applied it if the task is possible to evaluate in peer evaluating whereas the second lecturer always provide an evaluation after he assessed learners' task. Evaluation is an activity applied after assessment session is over. It is used to analyze the relationship between learners' score with learners' ability, and another related thing.

\subsubsection{Daily Test, Middle Test, and Final Test in Literary Course}

The first lecturer facilitates learners' daily test, middle test, and final test. He said,

"I provided them lattice work. Then for middle and final test, I commanded them to analyze literary work".

The lecturer chooses lattice work as daily test and text analysis for middle test and final test. He emphasizes text analysis in learning activity and test because it is the focus point in this course.

The second lecturer said that he replaced the daily test, the middle test, and the final test with the portfolio task. All tests usually form as literature response but they have different complexity level. Then the text and the demand are different.

The first lecturer preferred to analyzing text as their test. The lecturer here observes learners ability in interpret some kind of literary term for instance. It can be classified as objective test. The objective test is the test must be implemented scientifically. It relates to logical idea as the reaction to the test. Zhen (2012) states that the objective test can include some data, facts, or some literary terms to interpret, while the subjective test can be some essay questions, a summary, or a term paper.

Second lecturer preferred to respond text as learners' test. Lecturer focuses on how learners relate the text with their self. It can be classified as subjective text. The subjective test is the test involved learners personal contribution. Personal response toward text is one of example of this test. It also can be done by spoken or written form. As for the oral form, learners are supposed to articulate their personal responses to the text and answer some random questions raised by teachers; as for the written form, it has many ways (Zhen, 2012).

Second lecturer said that all text response result collected in portfolio. Portfolio, then, replaced daily test, middle test, and final test. Portfolios are structured, focused, and purposeful collections of student work.

\section{Literature Lecturers' Reflection}

This part is session for lecturers to reflect his teaching since planning, implementation, until evaluation. The lecturer can note the weakness and the advantage behind those activities. Then the most crucial thing is he can change, add, 
or modify his teaching for the next year in literature course. Here is the interview result about literature teaching reflection with lecturer of Introduction of Literature as first lecturer and lecture of Literary Work Analysis as second lecturer.

The first lecturer said,

"Literature course itself should have to divide into two parts. The

first part is analyzing literary work and the second part is literary practice".

So the lecturer difficulty in teaching literature is the confusion behind the name of literature course. The lecturer actually is the lecturer of Doing Drama course. He argued that the name of the course must be replaced by Literary Practice because he said

"Well the doing drama course is actually literary practice. So I just recommend to replace the name with literary practice".

The second lecturer said,

"Ok. I think class management is one of difficulty, e.g. it's quiet difficult to engage the low motivated students to be active during the class discussion".

So he argued that the difficulty in his teaching is class management. His other barrier is the way to handle the class. He also added,

"Yes, maybe because students are many I must manage classroom".

\section{DISCUSSION}

Both of lecturers have different argument about the advantage of teaching literature. The first lecturer talks about enjoyment in literary work. It should makes learner enjoys such kind literary work. The second lecturer talks about critical literacy as the advantage of responding literary work. It means that learners who can enjoy literary work so they can join to the nest step namely responding text critically.

The researcher had found that the two lecturers had designed learning syllabus, implementation, and evaluation inside. Both lecturers had decided learning objective in their syllabus and its' achievement is certainly affected by lecturers' preparation, learning activity in classroom, and so forth. The researcher, then, found contribution of literature teaching from learners' involvement as respondents in this research, that is, learners involved their personal experience in responding text as aesthetic demand in reader response theory proposed by Rosenblatt. This is the learning objective of "Literary Work Analysis" course and it means that the expected achievement in this course is achieved. Another contribution from "Introduction to Literature" course that should be found in this present research is learners' ability to analyze language device, figurative language for instance, in responding literary works. Analyzing language device actually supports learners to understand the content of literary work and catch meaning inside therefore it helps them to involve their personal experience inside. All learners, however, can't analyze figurative language in literary works and it means that learning objective in this course has not achieved. Learner's achievement in "Literary Work Analysis" course can be traced from learners' spoken response although it did not happen in their written response. On the other hand, all learners can't analyze figurative language as the prominent point in literary work. They just realized its' presence and it happened in their spoken and written response. Nobody related their analysis of language device with their 
personal involvement in their response whereas it actually can sharpen their personal response toward literary works.

All respondents had responded text directly and they had shorter time in it but their engagement with text was better in spoken response than written response. They said that they passed same stages whether in spoken or written response. They just had additional time to gain information about poets' and literary works' background and put it into their written response.

The researcher, however, found that almost all learners only involved their personal experience in their spoken response except learner B because she is the only one who still keeps her personal experience in written response. It absolutely opposites with their statement that they had same stages in responding literary work directly and indirectly. It actually proves that there is some factor affected their change from spoken to written response. The researcher breaks the factor into external and internal factor. Their external factor is the guidance from researcher when they stated their spoken response therefore it explored their response. Their internal factor is their own response stages. Learner A started her response activity by reading text first then continued by responding text. Learner B started her response activity by reading literary work first, looking the title, poet, then responding literary work. Learner $\mathrm{C}$ started her response activity by reading text repeatedly, interpreting and responding literary works. Their difference stages are the internal factor affected their spoken or written response. Learner B had more stages therefore her spoken and written response contained complete information and her personal experience emerged inside. Learners' spoken and written response aesthetically did not involve their analysis toward figurative language that can sharpen their aesthetic response. They actually had stated their reason for this case in first interview in this present research. They said that they can find the presence of figurative language inside literary works but they can't analyze it because there are many kinds of figurative language so it makes them confuse to decide kind of figurative language they found in literary works. It can be concluded that their less ability in analyzing figurative language comes from two reasons. The first reason is their less engagement with learning activity when they learnt figurative language. The second reason is their activity frequency to analyze figurative language inside literary work for formal or informal setting.

\section{CONCLUSION}

The second question is about the way EFL learners respond text directly and indirectly. All respondents had responded text directly and they had shorter time in it but their engagement with text was better in spoken response than written response. They said that they passed same stages whether in spoken or written response. They just had additional time to gain information about poets' and poems' background and put it into their written response. The researcher actually had observed all respondents' reading activity. The researcher observed that learner A passed some activities like read a poem, opened dictionary and discussed the poem with learner B because they joined spoken response session together. It makes their reading activity similar. It also leads them to have similar view about the poems' content but they still keep their own personal reaction when they were stating their spoken response. The learner $\mathrm{C}$ did spoken response alone therefore she created her own view and interpretation toward poems. The researcher also guided respondents some questions to explore their personal response and their analysis 
related to literary device toward poem. The researcher, however, found that all learners only involved their personal experience in their spoken response except learner B because she is the only one who still keeps her personal experience in written response. It absolutely opposites with their statement that they had same stages in responding poem directly and indirectly. It actually proves that there is some factor affected their change from spoken to written response.

The researcher breaks the factor into external and internal factor. Their external factor is the guidance from researcher when they stated their spoken response therefore it explored their response. Their internal factor is their own response stages. Learner A started her response activity by reading text first then continued by responding text. Learner B started her response activity by reading poem first, looking the title, poet, then responding poem. Learner $\mathrm{C}$ started her response activity by reading text repeatedly, interpreting and responding poems. Their difference stages are the internal factor affected their spoken or written response. Learner B had more stages therefore her spoken and written response contained complete information and her personal experience emerged inside. Learners' spoken and written response aesthetically did not involve their analysis toward figurative language that can sharpen their aesthetic response. They actually had stated their reason for this case in first interview in this present research. They said that they can find the presence of figurative language inside poems but they can't analyze it because there are many kinds of figurative language so it makes them confuse to decide kind of figurative language they found in poems. It can be concluded that their less ability in analyzing figurative language comes from two reasons. The first reason is their less engagement with learning activity when they learnt figurative language. The second reason is their activity frequency to analyze figurative language inside poem for formal or informal setting.

\section{REFERRENCES}

Ary et al. (2010). Introduction to Research Education ( $8^{\text {th }}$ ed). USA: Wadsworth.

Baker Linda \& Wigfield Allan. (1999). Dimensions of Children's Motivation for Reading and Their Relations to Reading Activity and Reading Achievement. Reading Research Quarterly, 34, 452-477, International Reading Association.

Beach Richard. (1993). Reader-Response Theories. United States of America: NCTE.

Creswell John W. (2012). Educational Research: Planning, Conducting and Evaluating Quantitative and Qualitative Research. Fourth Edition, United States of America: Pearson Education.

Garzon Eliana \& Pena Harold Castaneda. (2015). Applying the Reader-Response Theory to Literary Texts in EFL-Pre-Service Teacher's Initial Education. Canadian Center of Science and Education, 8(8).

Herlina Nirma, (2016). Teaching Literature Through Poetry: A Shifting Reading Orientation From Efferent To Aesthetic. Edulite, Journal of English Education, Literature, and Culture, 1(2). 
Hwang Diana \& Embi Mohamed Amin. (2007). Approaches Employed By Secondary School Teachers to Teaching The Literature Component in English. Jurnal Pendidik dan Pendidikan, Jil. 22, 1-23.

Hughes Janette. (2007). Poetry: A Powerful Medium for Literacy and Technology

Development. The Literacy and Numeracy Secretariat.

Jones Jane. (1998). Lesson planning: Towards purposeful learning and effective teaching. Encuentro. Revista de Investigación e Innovación en la clase de idiomas,10,1998.

Lehtonen Mikko. (2000). The Cultural Analysis of Texts. Sage Publications: London, Thousand Oaks, New Delhi.

Lobo $^{2}$ Alejandra Giangiulio. (2013). Reader-Response Theory: A Path Towards Wolfgang Iser. Letras 54.

Rosenblatt Louise M. (1994). The Reader, The Text, The Literary work: The Transactional of Literary Work. Southern Illinois University: The Board of trustees. Sanders April. (2012). Rosenblatt's Presence in the New Literacies Research. In the National Council of Teachers of English, 24(1).

Wiliam Dylan. (2013). Assessment: The Bridge between Teaching and Learning. National Council of Teachers of English, Voices from the Middle, December 2013.

Zhen Chen. (2012). Characteristics and Strategies of Literature Teaching in the EFL Context in China. International Journal of Electronics and Communication Engineering. 